Note

\section{The Role of Mannan-degrading Enzymes in the Lysis of Some Plant Pathogenic Filamentous Fungi, Glomerella Species}

\author{
Reiko Watanabe* and Nagahiro Ogasawara \\ Department of Agricultural Chemistry, Faculty \\ of Agriculture, Niigata University, \\ Niigata 950-21, Japan \\ * Niigata Women's College, Niigata 950, Japan
}

Received July 19, 1989

We have reported that the combined use of non-ionic detergents, such as Emulgen 120, and lytic enzymes provides a new screening method for fungicides which influence the biosynthesis system for the cell surface layers of fungi. "' However, there are filamentous fungi which are hardly lysed with the individual or simultaneous use of the following enzymes; a fungal lytic enzyme complelx from Bacillus circulans WL 12 (WL 12 enzyme), ${ }^{2 !}$ a snail enzyme, zymolyase and some kinds of proteases. Accordingly, to apply this screening method to more and various sorts of filamentous fungi, enzymes with other lytic activities are required. In addition, such enzymes are also required for studies on the cytological structure of the membrane, because protoplasts of Scedosporium sp. A-4 (a gaseous hydrocarbon utilizer ${ }^{3)}$ are hardly formed with the use of the above enzymes. Streptomyces No. 94a and No. 1391, which produce lytic enzymes, were selected when three (Glomerella cingulata, Ceratocystis fimbriata and Scedosporium sp. A-4) among many strains which are hardly lysed by the above enzymes were used as carbon sources. As a result, both strains were found to produce strong mannan-degrading enzymes. The details of these streptozymes will be presented elsewhere. This paper deals with the fact that mannan-degrading enzymes as well as glucanases, etc. are essential for the degradation of the mycelia of some kinds of filamentous fungi.

G. cingulata G 4-1-4 and Scedosporium sp. A-4 were cultured according to the previous papers. ${ }^{3.4)} \mathrm{C}$. fimbriata, supplied by Dr. Uritani of Nagoya University, was cultured at $28^{\circ} \mathrm{C}$ in the liquid medium used by Alviano et $a l^{5}{ }^{5}$ The mycelium of each fungus was harvested from a $48 \mathrm{hr}$-culture. Preparation of cell walls was performed according to Tanaka et al., ${ }^{2)}$ and the isolation and fractionation of the surface polysaccharides of each fungus according to Raschke and Ballou ${ }^{6 /}$ and Lloyd. ${ }^{7}$ Other experimental methods were similar to those described previously." For protoplast formation, the young mycelium after 16-20 hr cultivation was collected. Fifty $\mathrm{mg}$ (wet weight) of mycelium was added to $4.0 \mathrm{ml}$ of a lytic enzyme solution containing $0.6 \mathrm{M} \mathrm{MgSO}_{4}$ or $\mathrm{KCl}$ and $2 \mathrm{~mm}$ $\mathrm{MgCl}_{2}$ in $0.1 \mathrm{M}$ citric acid- $\mathrm{Na}_{2} \mathrm{HPO}_{4}$ buffer, pH 6.5, followed by incubation at $30^{\circ} \mathrm{C}$ with gentle shaking. The activity of the mannan-degrading enzymes was assayed at $37^{\circ} \mathrm{C}$, using Saccharomyces cerevisiae mannan (Dmannose, $>94 \%$ ) as a substrate. The enzyme solution $(0.5 \mathrm{ml})$ was added to $1 \mathrm{mg} \%$ mannan dissolved in $0.5 \mathrm{ml}$ of $50 \mathrm{~mm}$ potassium phosphate buffer, $\mathrm{pH}$ 6.5. After incubation for $1 \mathrm{hr}$, the liberated mannose was measured by the method of Somogyi-Nelson. ${ }^{8}$ One unit of the activity was defined as the amount of enzyme which liberated $1 \mu \mathrm{M}$ of D-mannose per hour. Preparation of the WL 12 enzyme, and the assaying of $\beta-1,3$-glucanase, chitinase and cell wall lysis were performed as described by Tanaka et al. ${ }^{1,21}$

The enzyme from Streptomyces No. 94a exhibits cell wall lytic activity (relative activity, 90\%), $\beta-1,3$-glucanase activity (relative activity, $68 \%$ ) and a trace of chitinase activity. Relative activity was expressed as the percentage compared with the activity of the WL 12 enzyme. Furthermore, this enzyme exhibited mannan-degrading activ-

Table I. Chemical Compositions of the Cell Walls

\begin{tabular}{cccccccc}
\hline Organism & $\begin{array}{c}\text { Carbohydrate } \\
(\%)\end{array}$ & (Glucose & Galactose & Mannose & Rhamnose $)^{b}$ & $\begin{array}{c}\text { Hexosamine } \\
(\%)\end{array}$ & $\begin{array}{c}\text { Protein } \\
(\%)\end{array}$ \\
\hline $\begin{array}{c}\text { Glomerella } \\
\text { cingulata }\end{array}$ & 73.8 & $(92.0$ & 4.5 & 3.6 & $0)$ & 4.9 & 8.2 \\
$\begin{array}{c}\text { Ceratocystis } \\
\quad \text { fimbriata }\end{array}$ & 55.4 & $(56.3$ & 14.9 & 28.9 & $0)$ & 13.0 & 23.4 \\
$\begin{array}{c}\text { Scedosporium } \\
\text { sp. A-4 }\end{array}$ & 24.6 & $(58.2$ & 5.8 & 23.0 & $13.0)$ & 23.9 & 42.5 \\
$\begin{array}{c}\text { Pyricularia } \\
\text { oryzae } \mathbf{P}_{2}\end{array}$ & 74.0 & $(93.2$ & 0.8 & 6.0 & $0)$ & 11.3 & 4.3 \\
\hline
\end{tabular}

a Total neutral carbohydrates determined by the phenol-sulfuric acid method.

$b$ The ratio of sugar components calculated on GLC.

c Determined by the Elson-Morgan method as modified by Arima et al. with glucosamine as a standard. 
Table II. Chemical Compositions of the Surface Polysaccharides

\begin{tabular}{ccccccc}
\hline Organism & $\begin{array}{c}\text { Carbohydrate } \\
(\%)\end{array}$ & (Glucose & Galactose & Mannose & Rhamnose $)^{b}$ & $\begin{array}{c}\text { Protein } \\
(\%)\end{array}$ \\
\hline $\begin{array}{c}\text { Glomerella } \\
\text { cingulata } \\
\begin{array}{c}\text { Ceratocystis } \\
\text { fimbriata }\end{array}\end{array}$ & 94.6 & $(0.8$ & trace & 98.4 & 0 & 4.8 \\
$\begin{array}{c}\text { Scedosporium } \\
\text { sp. A-4 }\end{array}$ & 88.5 & $(0.7$ & 34.9 & 64.4 & $0)$ & 8.7 \\
\hline
\end{tabular}

a.b See Table I.

ity $(4.6 \mathrm{u} / \mathrm{mg})$ and alkaline protease activity $(0.23 \mathrm{u} / \mathrm{mg})$, although the WL 12 enzyme, which was induced with the mycelium of Pyricularia oryzae or $G$. cingulata as a source of carbon, does not exhibit mannan-degrading or protease activity. When we examined the protoplast formation of $G$. cingulata mycelium using this enzyme, the protoplasts amounted to $4.4 \times 10^{6} / \mathrm{ml}$ with the streptozyme alone and increased about five-fold $\left(2.4 \times 10^{7} / \mathrm{ml}\right)$ with the addition of the WL 12 enzyme, while the WL 12 enzyme alone hardly produced any protoplasts. Under the same conditions, a similar phenomenon was observed for C. fimbriata, Scedosporium sp. A-4, seven other strains of Glomerella species, and Alternaria and Aspergillus species. The cell walls probably contain chitin or a chitin-like substance, because hexosamine was detected (Table I). However, chitinase does not participate in protoplast formation. The protease activity of this streptozyme was inhibited about $60 \%$ on the addition of excess SSI, whereas protoplast formation was hardly affected. Hence, the protease seems not to be necessary for the protoplast formation of $G$. cingulata and $C$. fimbriata except for Scedosporium sp. A-4 with a higher protein content (Tables I and II).

We further examined as to whether or not the surface polysaccharides of these fungal cell walls are related with protoplast formation. Of the carbohydrates of these cell walls themselves, glucose showed 56.3 to $93.2 \%$ of the sugar components of each cell wall, being the main component. The composition of the cell wall of $G$, cin- gulata was not significantly different from that of $P$. oryzae lysed by the WL 12 enzyme (Table I). Of these fungal surface polysaccharides, mannose showed 50.8 to $98.4 \%$ of each carbohydrate, being the main component (Table II). The polysaccharides containing mainly mannan will also be the major surface components in plant pathogenic fungi such as the Ceratocystis species reported by Alviano et al. $^{51}$ and Glomerella species.

These results indicate that mannan-degrading enzymes play an important role in the lysis of the mycelia of these fungi.

\section{References}

1) R. Watanabe, N. Ogasawara, H. Tanaka and T. Uchiyama, Agric. Biol. Chem., 52. 895 (1988).

2) H. Tanaka, N. Ogasawara, T. Nakajima and K. Tamari, J. Gen. Appl. Microbiol., 16, 39 (1970).

3) M. Onodera, Y. Endo and N. Ogasawara, Agric. Biol. Chem., 53, 1431 (1989).

4) R. Watanabe, T. Hoshino and N. Ogasawara, Agric. Biol. Chem., 50, 325 (1986).

5) C. S. Alviano, P. A. J. Gorin and L. R. Travassos, Exp. Mycol., 3, 174 (1979).

6) W. C. Raschke and C. E. Ballou, J. Bacteriol., 100, 1175 (1969).

7) K. O. Lloyd, Biochemistry, 9, 3446 (1970).

8) M. Somogyi, J. Biol. Chem., 195, 19 (1952). 